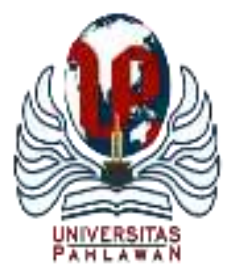

\title{
JURNALBASICEDU
}

Volume 5 Nomor 6 Tahun 2021 Halaman 5984 - 5994

Research \& Learningin Elementary Education

https://jbasic.org/index.php/basicedu

\section{Pengembangan Media Siduwan (Siklus Hidup Hewan) Berbasis Macromedia Flash di Sekolah Dasar}

\author{
Alvin Vikiantika $^{1 凶}$, Ita Kurnia ${ }^{2}$, Dwi Novia Rachmawati ${ }^{3}$ \\ Universitas Nusantara PGRI Kediri, Indonesia ${ }^{1,2,3}$ \\ E-mail: alvinviki04@gmail.com ${ }^{1}$, itakurnia@ unpkediri.ac.id ${ }^{2}, \underline{\text { dwinoviarachmawati@gmail.com }}^{3}$
}

\begin{abstract}
Abstrak
Proses pembelajaran yang dilaksanakan di SDN Lirboyo 2 selama pandemi tidak bisa berlangsung secara maksimal. Hal ini disebabkan oleh minimnya penggunaan media pembelajaran. Guru kesulitan untuk memberikan media secara konkret pada materi tahapan siklus hidup hewan secara online. Ini menyebabkan menurunnya hasil belajar siswa. Atas dasar permasalahan tadi, peneliti membuat media SIDUWAN. Tujuan penelitian ini untuk mengukur kevalidan, kepraktisan, dan keefektivan media SIDUWAN. Penelitian ini menggunakan metode Research and Development (R\&D) dengan model pengembangan ADDIE. Hasil validasi materi $78 \%$ serta media 94\%, validasi kepraktisan 93\% dan 97\%, serta uji keefektifan 0,003 dan 0,002. Dari hasil tersebut nampak bahwa materi pada media valid, dapat dipergunakan dengan revisi kecil. Selain itu, media yang dikembangkan sangat valid, sangat praktis, dan sangat efektif. Jadi dapat disimpulkan bahwa media SIDUWAN valid, praktis, dan efektif untuk dipergunakan sebagai media pembelajaran pada materi siklus hidup hewan di kelas IV.
\end{abstract}

Kata Kunci: media pembelajaran, siklus hidup hewan, macromedia flash 8.0

\section{Abstract}

The learning process at SDN Lirboyo 2 during the pandemic could not take place optimally. It is cause less use of learning media. The teacher finds it difficult to provide concrete media on the material on the stages of the animal life cycle by online learning. The effect is student studying result are lowering. Basis of these problems, researchers developed learning SIDUWAN media. The purpose of this study was to measure the validity, practicality, and effectiveness of the SIDUWAN media. It is research and development or Research and Development $(R \& D)$ with the ADDIE development model. The results of the material validity test are $78 \%$ and the media are $94 \%$, the practicality test is $93 \%$ and $97 \%$, and the effectiveness test is 0.003 and 0.002. From these results it appears that the material on the media is valid, it can be used with minor revisions. In addition, the media developed is very valid, very practical, and very effective. So it can be concluded that the learning SIDUWAN media is valid, practical, and effective to be used as a learning medium for animal life cycle material in fourth class.

Keywords: learning media, animal life cycle, Macromedia Flash 8.0

Copyright (c) 2021 Alvin Vikiantika, Ita Kurnia, Dwi Novia Rachmawati

$\triangle$ Corresponding author :

Email : alvinviki04@gmail.com

ISSN 2580-3735 (Media Cetak)

DOI $\quad$ : https://doi.org/10.31004/basicedu.v5i6.1748

ISSN 2580-1147 (Media Online) 


\section{PENDAHULUAN}

Kurikulum 2013 (K13) adalah pembaharuan dari kurikulum KTSP yang sudah diterapkan sebelumnya (Suparyanti, Ratnawati, Arwin, 2017). Konsep K13 menitikberatkan pada penguatan soft skills dan hard skils yang mencakup aspek kompetensi sikap, keterampilan, serta pengetahuan (Fadillah, 2014). Pernyataan tersebut senada dengan peraturan yang berasal dari Permendikbud Nomor 57 Tahun 2014 Pasal 5 yang menyatakan bahwa "Mata pelajaran umum Kelompok A sebagaimana dimaksud pada ayat (1) huruf a artinya program kurikuler yang bertujuan untuk membuat kompetensi sikap, kompetensi pengetahuan, dan kompetensi keterampilan peserta didik sebagai dasar serta penguatan kemampuan dalam kehidupan bermasyarakat, berbangsa, dan bernegara". Ilmu Pengetahuan Alam (IPA) tergolong ke dalam mata pelajaran umum kelompok A.

Keaktifan peserta didik pada proses pembelajaran IPA ialah inti dari pola belajar bermakna (Muakhirin, 2014). Dimana peserta didik mampu menghubungkan informasi atau materi pelajaran baru menggunakan konsep yang telah ada selain itu dapat diimplementasikan dalam kehidupan sehari-hari. Pernyataan tersebut selaras dengan pernyataan Ausubel, yang telah dipaparkan oleh Burhanuddin (1996:112) dimana Ausubel memaparkan bahwa pembelajaran bermakna adalah proses mengaitkan antara informasi yang telah dimiliki seseorang dengan informasi baru yang diperoleh. Disinilah dibutuhkan peran aktif berasal dari guru untuk membentuk lingkungan belajar bermakna, terutama pada mata pelajaran IPA. Dimana isi Kompetensi Dasar (KD) yang difokuskan yaitu "Membandingkan siklus hidup beberapa jenis makhluk hidup serta mengaitkan dengan upaya pelestariannya". Namun, berdasarkan hasil wawancara dengan wali kelas IV yang sudah dilaksanakan di SDN Lirboyo 2 diperoleh informasi bahwa guru belum menyajikan penjelasan secara rinci tentang urutan siklus hidup hewan yang mengalami metamorfosis dan tanpa mengalami metamorfosis. Serta juga guru kesulitan untuk memberikan contoh secara konkret tentang tahapan siklus hidup hewan dikarenakan keterbatasan ketika pembelajaran. Begitu juga dengan materi yang disampaikan hanya disajikan berupa video pembelajaran yang diambil dari channel Youtube. Kondisi seperti ini yang menyebabkan membelajaran kurang bermakna ini menyebabkan peserta didik hanya dituntut untuk mengingat tanpa diiringi dengan pemahaman dan pengimplementasian dalam aktivitas peserta didik sehari-hari (Arina, D., Mujiwati, E.S., Kurnia, 2020). Disini belum tercipta lingkungan belajar bermakna dalam pembelajaran daring selama pandemi Covid 19 (Safitri, A., Putri, F.S., Fauziyyah, H., 2021). Akibatnya masih terdapat hasil belajar peserta didik yang kurang dari kriteria ketuntasan minimal (KKM) seperti halnya penelitian yang dilakukan oleh (Muwaffaq \& Lilik, 2017).

Media pembelajaran yang dibuat harus memenuhi standar, diantaranya: (1) kesesuaian dengan tujuan pembelajaran, (2) tampilan dan isi sesuai dengan konsep pembelajaran, (3) pengemasan media harus praktis, luwes, dan bertahan, dan (4) media pembelajaran harus mudah digunakan oleh pengguna (Arsyad, 2014). Tujuan adanya inovasi pengembangan media pembelajaran untuk mempermudah pengguna dalam menyampaikan maupun menerima materi terkait siklus hidup hewan sekaligus dapat menciptakan lingkungan belajar aktif sehingga dapat mempengaruhi dalam peningkatan hasil belajar siswa (Faridy et al., 2019). Salah satu media yang tepat untuk diterapkan yaitu media pembelajaran yang memanfaatkan software Macromedia Flash 8.0 (Karunia, 2017). Macromedia Flash 8.0 adalah software pada computer yang digunakan untuk membuat animasi pada media pembelajaran (Pratiwi, M.A., \& Jasril, 2019). Kelebihan dari aplikasi ini diantaranya memiliki fitur yang berupa animasi serta dapat dapat disajikan secara interaktif sehingga dapat meningkatkan minat belajar peserta didik (Yuniasti \& Wulandari, 2015).

Oleh karena itu, penelitian ini dilaksanakan dengan tujuan: (1) Untuk mengetahui kevalidan media SIDUWAN kelas IV pada SDN Lirboyo 2 Kota Kediri; (2) Untuk mengetahui kepraktisan media SIDUWAN kelas IV di SDN Lirboyo 2 Kota Kediri; (3) Untuk mengetahui keefektifan media SIDUWAN kelas IV di SDN Lirboyo 2 Kota Kediri. 
DOI: https://doi.org/10.31004/basicedu.v5i6.1748

\section{METODE PENELITIAN}

Metode yang digunakan dalam penelitian ini yaitu Research and Development (R\&D). Metode ini adalah metode penelitian yang dipergunakan dalam membuat produk serta menguji keefektifan produk tersebut (Sugiyono, 2016). Senada dengan pendapat Sugiyono seperti halnya disampaikan oleh Mulyatiningsih (2011: 145) menyatakan bahwa "Penelitian dan pengembangan (research and development) bertujuan untuk menghasilkan produk baru dengan melewati proses pengembangan". Berasal kedua pendapat tersebut, bisa disimpulkan bahwa penelitian dan pengembangan merupakan penelitian yang dipergunakan untuk membuat produk baru, serta mevalidasi dan mengetahui keefektifannya.

Adapun model pengembangan yang dipergunakan adalah ADDIE yang dikembangkan oleh Robert Maribe Branch (2009) seperti halnya disampaikan oleh Sugiyono (2016:38). Model pengembangan ADDIE terdiri dari lima tahapan yang mencakup analisis (analysis), desain (design), pengembangan (development), implementasi (implementation) dan evaluasi (evaluation) (Sugiyono, 2015). Menurut (Gafur, 2012), pengembangan model ADDIE digambarkan sebagai berikut.

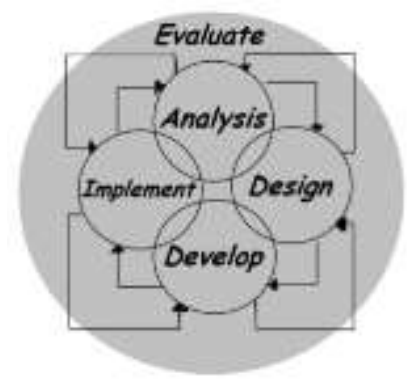

\section{Gambar 1: Model Desain Pengembangan ADDIE (Sumber: (Gafur, 2012))}

Data pada penelitian berasal dari siswa SDN Sukorame 4 dan SDN Lirboyo 2. Dimana sampel skala kecil diambil 8 siswa kelas IV berasal SDN Sukorame 4 serta skala besar diambil 52 siswa kelas IV dari SDN Lirboyo 2. Teknik pengumpulan data memakai soal pretest-postest serta kuisioner. Soal pretest-postest berasal dari 20 soal yang akan diperoleh hasil berupa skor. Sedangkan kuisioner berisi instrumen yang telah dibuat peneliti untuk mengetahui pendapat ahli atau validator dan respon siswa terkait kelayakan dari pengembangan media SIDUWAN. Instrument yang dipergunakan dalam pengambilan data yaitu (1) lembar instrument validasi penilaian ahli media, (2) lembar instrument validasi penilaian ahli materi, (3) lembar instrument validasi ahli praktisi pembelajaran, (4) lembar instrumen angket respon siswa. Data yang diperoleh selanjutnya diolah menggunakan teknik analisis menggunakan skala likert serta disesuai kan dengan kriteria validitas (Djaali, 2008).

Pemberian skor yang dilakukan oleh para ahli yaitu ahli media, materi, praktisi pembelajaran, serta respon siswa menggunakan kategori sangat baik (5), baik (4), cukup (3), kurang (2), dan sangat kurang (1). Dari hasil penilaian tersebut diberikan penilaian validasi dengan rumus :

$$
(\mathrm{V}-\mathrm{ah})=\mathrm{TSe} / \mathrm{TSh} \times 100 \%=\ldots . . \%
$$

Keterangan :

TSe : total skor empirik

TSh : total skor maksimal 
5987 Pengembangan Media Siduwan (Siklus Hidup Hewan) Berbasis Macromedia Flash di Sekolah Dasar - Alvin Vikiantika, Ita Kurnia, Dwi Novia Rachmawati

DOI: https://doi.org/10.31004/basicedu.v5i6.1748

Tabel 1. Kriteria kevalidan secara deskriptif (Akbar, 2013)

\begin{tabular}{|c|c|c|}
\hline Pencapaian Nilai (Skor) & Kategori Validitas & Keterangan \\
\hline $0 \%-20 \%$ & Tidak Valid & Tidak boleh digunakan \\
\hline $21 \%-40 \%$ & Kurang Valid & Tidak boleh digunakan \\
\hline $41 \%-60 \%$ & Cukup Valid & Boleh digunakan setelah revisi besar \\
\hline $61 \%-80 \%$ & Valid & Boleh digunakan dengan revisi kecil \\
\hline $81 \%-100 \%$ & Sangat Valid & Sangat baik untuk digunakan \\
\hline
\end{tabular}

Pengolahan data pada penelitian ini memakai Software SPSS Versi 23. Pada tingkat kevalidan soal diukur dengan menggunakan perhitungan Compare Means- One-Sample T Test dengan tingkat kriteria kurang dari 0,05. Tingkat realibilitas soal diukur menggunakan Scale - Realibility Analysis dengan minimal tingkat realibilitas soal lebih dari 300. Untuk mengetahui hasil keefektifan dari media, dibandingkan dengan kriteria perbandingan pada taraf signifikansi 5\%. Apabila nilai signifikansi kurang dari 0,05 maka H0 ditolak, memiliki arti bahwa terdapat dampak yang signfikan satu variable bebas terhadap variable terikat. Begitu juga sebaliknya, apabila nilai signifikansi > 0,05 maka H0 diterima, artinya tidak ada pengaruh yang signifikan antara variabel bebas dengan variabel terikat. Variabel bebas yang terdapat dalam penelitian dan pengembangan artinya media SIDUWAN (Siklus Hidup Hewan), sedangkan variable terikat adalah hasil belajar peserta didik kelas IV.

\section{HASIL DAN PEMBAHASAN}

\section{Hasil Kevalidan Media}

Hasil yang didapat dari penelitian dan pengembangan adalah kevalidan, kepraktisan, dan keefektifan yang berasal dari media SIDUWAN untuk menaikkan hasil belajar peserta didik kelas IV di SDN Lirboyo 2 Kediri. Hasil yang diperoleh dicantumkan pada tabel di bawah ini.

Tabel 2. Penilaian Media oleh Ahli Materi

\begin{tabular}{|c|c|c|}
\hline Rata-Rata Skor & Kategori Validitas & Keterangan \\
\hline $78 \%$ & Valid & $\begin{array}{c}\text { Boleh digunakan dengan revisi } \\
\text { kecil }\end{array}$ \\
\hline
\end{tabular}

Penilaian media oleh ahli materi dilihat dari rata-rata skor yaitu 78\% dengan kategori valid.

Tabel 3. Penilaian Media oleh Ahli Media

\begin{tabular}{|c|c|c|}
\hline Rata-Rata Skor & Kategori Validitas & Keterangan \\
\hline $94 \%$ & Sangat Valid & Sangat baik untuk digunakan \\
\hline
\end{tabular}

Penilaian media oleh ahli media dilihat dari rata-rata skor yaitu 94\% dengan kategori sangat valid.

Tabel 4. Penilaian Media oleh Ahli Praktisi Pembelajaran SDN Sukorame 4 Kediri

\begin{tabular}{|c|c|c|}
\hline Rata-Rata Skor & Kategori Validitas & Keterangan \\
\hline $97 \%$ & Sangat Valid & Sangat baik untuk digunakan \\
\hline
\end{tabular}

Penilaian media oleh ahli praktisi pembelajaran SDN Sukorame 4 Kediri dilihat dari rata-rata skor yaitu 97\% dengan kategori sangat valid. 

- Alvin Vikiantika, Ita Kurnia, Dwi Novia Rachmawati

DOI: https://doi.org/10.31004/basicedu.v5i6.1748

Tabel 5. Penilaian Media oleh Ahli Praktisi Pembelajaran SDN Lirboyo 2 Kediri

\begin{tabular}{|c|c|c|}
\hline Rata-Rata Skor & Kategori Validitas & Keterangan \\
\hline $93 \%$ & Sangat Valid & Sangat baik untuk digunakan \\
\hline
\end{tabular}

Penilaian media oleh ahli praktisi pembelajaran SDN Lirboyo 2 Kediri dilihat dari rata-rata skor yaitu 93\% dengan kategori sangat valid.

\section{Hasil Kepraktisan Media}

Tabel 6. Hasil Analisis Data Respon Siswa Kelompok Kecil SDN Sukorame 4 Kediri

\begin{tabular}{|c|c|c|c|c|c|c|c|c|c|c|c|}
\hline \multicolumn{12}{|c|}{ Statistics } \\
\hline & & $\begin{array}{c}\text { Kriteria_ } \\
1\end{array}$ & $\begin{array}{c}\text { Kriteria_ } \\
2\end{array}$ & $\begin{array}{c}\text { Kriteria_ } \\
3\end{array}$ & $\begin{array}{c}\text { Kriteria_ } \\
4\end{array}$ & $\begin{array}{c}\text { Kriteria_ } \\
5\end{array}$ & $\begin{array}{c}\text { Kriteria_ } \\
6\end{array}$ & $\begin{array}{c}\text { Kriteria_ } \\
7\end{array}$ & $\begin{array}{c}\text { Kriteria_ } \\
8 \\
\end{array}$ & $\begin{array}{c}\text { Kriteria_ } \\
9\end{array}$ & $\begin{array}{c}\text { Kriteria_ } \\
10\end{array}$ \\
\hline \multirow[t]{2}{*}{$N$} & Valid & 8 & 8 & 8 & 8 & 8 & 8 & 8 & 8 & 8 & 8 \\
\hline & Missing & 0 & 0 & 0 & 0 & 0 & 0 & 0 & 0 & 0 & 0 \\
\hline \multicolumn{2}{|c|}{ Mean } & 3.25 & 3.38 & 3.38 & 3.25 & 3.25 & 3.25 & 3.25 & 3.38 & 3.25 & 3.38 \\
\hline \multicolumn{2}{|c|}{ Median } & 3.00 & 3.00 & 3.00 & 3.00 & 3.00 & 3.00 & 3.00 & 3.00 & 3.00 & 3.00 \\
\hline
\end{tabular}

Hasil analisis data respon siswa kelompok kecil SDN Sukorame 4 Kediri berkisar antara rata-rata 3.25 3.38

Tabel 7. Hasil Analisis Data Respon Siswa Kelompok Besar SDN Lirboyo 2 Kediri

\begin{tabular}{|c|c|c|c|c|c|c|c|c|c|c|c|}
\hline \multicolumn{12}{|c|}{ Statistics } \\
\hline & & $\begin{array}{c}\text { Kriteria_ } \\
1\end{array}$ & $\begin{array}{c}\text { Kriteria } \\
2\end{array}$ & $\begin{array}{c}\text { Kriteria_ } \\
3\end{array}$ & $\begin{array}{c}\text { Kriteria_ } \\
4\end{array}$ & $\begin{array}{c}\text { Kriteria_ } \\
5\end{array}$ & $\begin{array}{c}\text { Kriteria_ } \\
6\end{array}$ & $\begin{array}{c}\text { Kriteria_ } \\
7\end{array}$ & \begin{tabular}{|c|} 
Kriteria_ \\
8
\end{tabular} & $\begin{array}{c}\text { Kriteria_ } \\
9\end{array}$ & $\begin{array}{c}\text { Kriteria_ } \\
10\end{array}$ \\
\hline \multirow[t]{2}{*}{$\bar{N}$} & Valid & 52 & 52 & 52 & 52 & 52 & 52 & 52 & 52 & 52 & 52 \\
\hline & Missing & 0 & 0 & 0 & 0 & 0 & 0 & 0 & 0 & 0 & 0 \\
\hline \multicolumn{2}{|c|}{ Mean } & 3.15 & 3.19 & 3.13 & 3.19 & 3.08 & 3.12 & 3.12 & 3.10 & 3.04 & 3.06 \\
\hline \multicolumn{2}{|c|}{ Median } & 3.00 & 3.00 & 3.00 & 3.00 & 3.00 & 3.00 & 3.00 & 3.00 & 3.00 & 3.00 \\
\hline
\end{tabular}

Hasil analisis data respon siswa kelompok kecil SDN Lirboyo 2 Kediri berkisar antara rata-rata 3.04 3.19 .

\section{Hasil Keefektifan Media}

Tabel 8. Hasil Analisis Perbandingan antara Pretes dan Postest Kelompok Kecil SDN Sukorame 4 Kediri

\begin{tabular}{|c|c|c|c|c|c|c|c|c|c|}
\hline \multicolumn{10}{|c|}{ Paíred Samples Test } \\
\hline & & \multicolumn{5}{|c|}{ Paired Differences } & \multirow[b]{3}{*}{$t$} & \multirow[b]{3}{*}{ df } & \multirow{3}{*}{$\begin{array}{l}\text { Sig. (2- } \\
\text { tailed) }\end{array}$} \\
\hline & & \multirow[b]{2}{*}{ Mean } & \multirow{2}{*}{$\begin{array}{c}\text { Std. } \\
\text { Deviation }\end{array}$} & \multirow{2}{*}{$\begin{array}{l}\text { Std. Error } \\
\text { Mean }\end{array}$} & \multicolumn{2}{|c|}{$\begin{array}{l}95 \% \text { Confidence Interval of } \\
\text { the Difference }\end{array}$} & & & \\
\hline & & & & & Lower & Upper & & & \\
\hline $\begin{array}{l}\text { Pair } \\
1\end{array}$ & $\begin{array}{l}\text { pretes - } \\
\text { postes }\end{array}$ & -17.500 & 11.019 & 3.896 & -26.713 & -8.287 & -4.492 & 7 & .003 \\
\hline
\end{tabular}

Hasil keefektifan media kelompok kecil SDN Sukorame 4 Kediri dilihat dari hasil Sig.(2-tailed) yaitu 0.003 
Tabel 9. Hasil Analisis Perbandingan antara Pretes dan Postest Kelompok Besar SDN Lirboyo 2 Kediri

\begin{tabular}{|c|c|c|c|c|c|c|c|c|c|}
\hline \multicolumn{10}{|c|}{ Paired Samples Test } \\
\hline & & \multicolumn{5}{|c|}{ Paired Differences } & \multirow[b]{3}{*}{$\mathrm{t}$} & \multirow[b]{3}{*}{ df } & \multirow{3}{*}{$\begin{array}{l}\text { Sig. (2- } \\
\text { tailed) }\end{array}$} \\
\hline & & \multirow[b]{2}{*}{ Mean } & \multirow{2}{*}{$\begin{array}{c}\text { Std. } \\
\text { Deviation }\end{array}$} & \multirow{2}{*}{$\begin{array}{l}\text { Std. Error } \\
\text { Mean }\end{array}$} & \multicolumn{2}{|c|}{$\begin{array}{c}95 \% \text { Confidence Interval of } \\
\text { the Difference }\end{array}$} & & & \\
\hline & & & & & Lower & Upper & & & \\
\hline Pair 1 & $\begin{array}{l}\text { pretes - } \\
\text { postest }\end{array}$ & -7.115 & 15.853 & 2.198 & -11.529 & -2.702 & -3.237 & 51 & .002 \\
\hline
\end{tabular}

Hasil keefektifan media kelompok kecil SDN Lirboyo 2 Kediri dilihat dari hasil Sig.(2-tailed) yaitu 0.002 .

\section{Pembahasan Hasil Kevalidan Media}

Kriteria kevalidan berdasarkan (Akbar, 2013), bila persentase hasil 61\% - 80\% maka dapat dikatakan valid dengan keterangan boleh digunakan dalam revisi kecil dan persentase $81 \%-100 \%$ dapat dikatakan sangat valid dengan keterangan sangat baik untuk digunakan. Pada analisis data validasi ahli materi menunjukkan hasil 78\%. Hal tersebut materi dalam media dapat digunakan dengan revisi kecil. Adapun saran dalam tahap evaluasi berupa penyesuaian tujuan pembelajaran dengan materi yang disampaikan dan soal penilaian mengacu pada ketercapaian tujuan pembelajaran.

Setelah melalui tahap evaluasi, media diujikan kepada ahli media dan menunjukkan hasil $94 \%$ sehingga media dapat dikatakan valid dengan keterangan sangat baik untuk digunakan. Terdapat saran dari ahli media terkait konsistensi jenis dan ukuran huruf serta warna pada tombol navigasi. Setelah evaluasi diperoleh produk akhir dan diujikan kepada ahli praktisi. Ahli praktisi dilakukan oleh guru kelas IV, baik skala kecil maupun skala besar. Hasil uji praktisi menunjukkan bahwa penilaian media oleh ahli praktisi pembelajaran SDN Sukorame 4 Kediri sebesar 97\% dan ahli praktisi pembelajaran SDN Lirboyo 2 Kediri sebesar 93\% dalam kategori sangat valid dengan keterangan sangat baik untuk dipergunakan. Pernyataan tersebut selaras dengan penelitian terdahulu oleh (Rahmi et al., 2019) bahwa media berbasis Macromedia Flash juga menunjukkan hasil yang validasi ahli materi I 98,33\%, ahli materi II 90\%, ahli media I 97,5\%, dan ahli media II $100 \%$ dengan kategori "Sangat Layak Digunakan". Hasil validasi ahli media dan ahli materi menunjukkan media pembelajaran berbasis Macromedia Flash dikatakan valid untuk dipergunakan pada tema pengalamanku kelas $2 \mathrm{SD}$.

\section{Pembahasan Hasil Kepraktisan Media}

Kriteria kevalidan berdasarkan (Akbar, 2013), bila persentase hasil 61\% - 80\% maka dapat dikatakan valid dengan keterangan boleh digunakan dalam revisi kecil dan persentase $81 \%$ - 100\% dapat dikatakan sangat valid dengan keterangan sangat baik untuk digunakan. Pada analisis data validasi ahli materi menunjukkan hasil 78\%. Hal tersebut materi dalam media dapat digunakan dengan revisi kecil. Adapun saran dalam tahap evaluasi berupa penyesuaian tujuan pembelajaran dengan materi yang disampaikan dan soal penilaian mengacu pada ketercapaian tujuan pembelajaran.

Setelah melalui tahap evaluasi, media diujikan kepada ahli media dan menunjukkan hasil $94 \%$ sehingga media dapat dikatakan valid dengan keterangan sangat baik untuk digunakan. Terdapat saran dari ahli media terkait konsistensi jenis dan ukuran huruf serta warna pada tombol navigasi. Setelah evaluasi diperoleh produk akhir dan diujikan kepada ahli praktisi. Ahli praktisi dilakukan oleh guru kelas IV, baik skala kecil maupun skala besar. Hasil uji praktisi menunjukkan bahwa penilaian media oleh ahli praktisi pembelajaran SDN Sukorame 4 Kediri sebesar 97\% dan ahli praktisi pembelajaran SDN Lirboyo 2 Kediri sebesar 93\% dalam kategori sangat valid dengan keterangan sangat baik untuk dipergunakan. Pernyataan tersebut selaras dengan penelitian yang telah dilaksanakan oleh (Rahmi et al., 2019) bahwa media berbasis Macromedia Flash juga 
DOI: https://doi.org/10.31004/basicedu.v5i6.1748

menunjukkan hasil yang validasi ahli materi I 98,33\%, ahli materi II 90\%, ahli media I 97,5\%, dan ahli media II 100\% dengan kategori "Sangat Layak Digunakan". Hasil validasi ahli media dan ahli materi menunjukkan media pembelajaran berbasis Macromedia Flash dikatakan valid untuk dipergunakan pada tema pengalamanku kelas $2 \mathrm{SD}$.

\section{Pembahasan Hasil Keefektifan Media}

Pada uji keefektifan media SIDUWAN diperoleh dari hasil perbandingan dari pemberian soal pretes dan postes masing-masing sebanyak 20 soal dengan memakai aplikasi SPSS Versi 23.

Pada tingkat kevalidan soal diukur dengan menggunakan perhitungan Compare Means- One-Sample T Test dengan tingkat kriteria kurang dari 0,05. Dari penelitian ini diperoleh hasil pretes dan posttest pada uji coba skala kecil dan skala besar memperlihatkan hasil yang sama. Nilai kevalidan kurang dari 0,05 , maka soal pretes dan posttes dapat dinyatakan $100 \%$ valid.

Tingkat realibilitas soal diukur menggunakan Scale - Realibility Analysis dengan minimal tingkat realibilitas soal lebih dari 300. Untuk tingkat realibilitas soal pretes dan postes skala kecil menunjukkan hasil yang sama yaitu 0,364 . Namun untuk skala besar, tingkat realibilitas pada soal pretes sebesar 0,621 dan posttest sebesar 0,358 .

Hasil dari pretest dan posttest dianalogikan dengan kriteria perbandingan pada taraf signifikansi $5 \%$. H0 ditolak jika nilai signifikansi kurang dari 0,05 dapat didefinisikan bahwa ada pengaruh yang signfikan variable bebas dengan variable terikat. Dan sebaliknya, H0 diterima jika nilai signifikansi lebih dari 0,05 dapat disimpulkan bahwa tidak ada pengaruh yang signifikan antara variabel bebas dengan variabel terikat. Variabel bebas dalam penelitian dan pengembangan ini yaitu media SIDUWAN (Siklus Hidup Hewan), sedangkan variable terikat pada penelitian ini yaitu hasil belajar peserta didik kelas IV. Hasil dari perbandingan antara uji awal (pretest) dan uji akhir (postest) pada skala kecil memiliki nilai signifikansi 0,003. Sedangkan nilai signifikansi untuk skala besar sebesar 0,002. Berdasarkan hasil perbandingan antara pretest dan postest dalam penelitian ini, terdapat pengaruh yang signifikan dalam penggunaan media SIDUWAN terhadap peningkatan hasil belajar peserta didik. Pernyataan tersebut senada dengan penelitian yang dilaksanakan oleh (Syabrina \& Sulistyowati, 2020) yang menyatakan bahwa media berbasis Macromedia Flash berpengaruh terhadap peningkatan hasil belajar peserta didik sebesar 36,58. Sehingga dapat diartikan bahwa hasil belajar peserta didik sesudah diberikan media berbasis Macromedia Flash meningkat dari hasil pembelajaran sebelumnya. Penelitian lain juga menunjukkan adanya peningkatan hasil belajar siswa dengan menggunakan multimedia (Riyadi \& Pardjono, 2014).

\section{Pembahasan Spesifikasi Media}

Penelitian ini mengembangkan media SIDUWAN untuk siswa kelas IV. Berikut paparan dari spesifikasi media yang dikembangkan.

a. Tampilan pada bagian pembuka disajikan nama media yaitu SIDUWAN (Siklus Hidup Hewan). Nama media berfungsi untuk memberikan informasi pada pengguna mengenai isi materi yang dipaparkan di dalam media yaitu tentang siklus hidup hewan. 


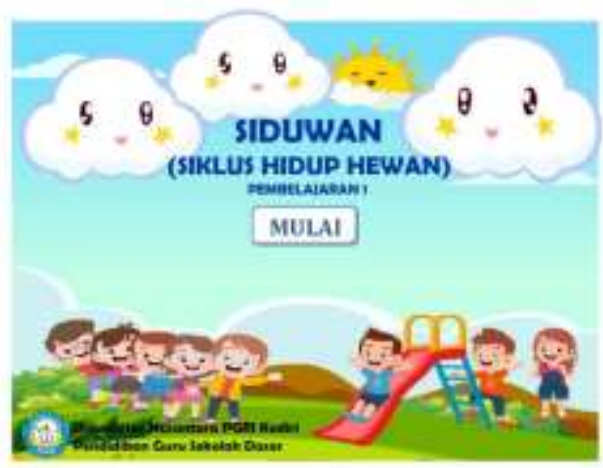

Gambar 2. Halaman awal

b. Menu utama. Pada menu ini mengemukakan beberapa sub menu yang terdiri atas identitas materi, materi, petunjuk penggunaan profil dan kuis. Pilihan dari sub menu dapat menjadi pilihan pengguna agar dapat menuju ke menu berikutnya. Beberapa sub menu tersebut bisa dipilih pengguna untuk menuju ke menu selanjutnya.

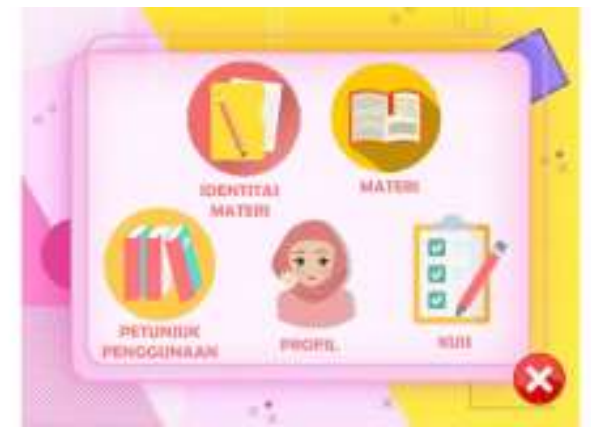

Gambar 3. Menu Utama

c. Menu identitas materi. Menu ini terdiri atas beberapa sub menu yang memaparkan Kompetensi Inti (KI), Kompetensi Dasar (KD), indikator dan tujuan pembelajaran dari materi siklus hidup hewan.

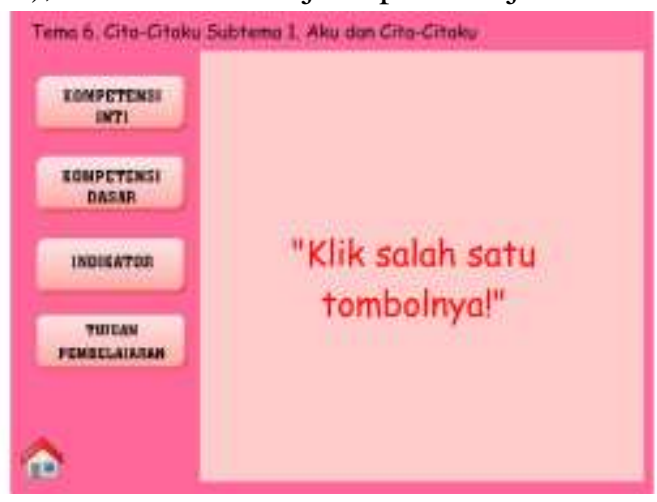

Gambar 4. Menu Identitas Materi

d. Menu materi. Menu ini menyajikan teks, animasi dan penjelasan berupa suara mengenai pengertian siklus hidup hewan, pembagian berdasarkan perubahan bentuknya. Pada menu ini juga disertai dengan gambar di setiap tahapan dari beberapa contoh hewan. 

- Alvin Vikiantika, Ita Kurnia, Dwi Novia Rachmawati

DOI: https://doi.org/10.31004/basicedu.v5i6.1748

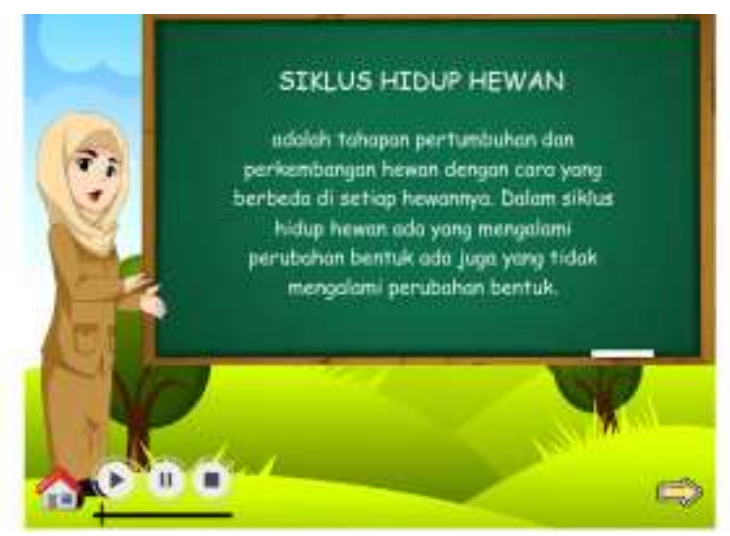

Gambar 5. Menu Materi

e. Menu petunjuk penggunaan. Pada menu ini ditampilkan penjelasan mengenai jenis-jenis tombol beserta fungsinya guna mempermudah pengguna dalam mengoperasikan media.

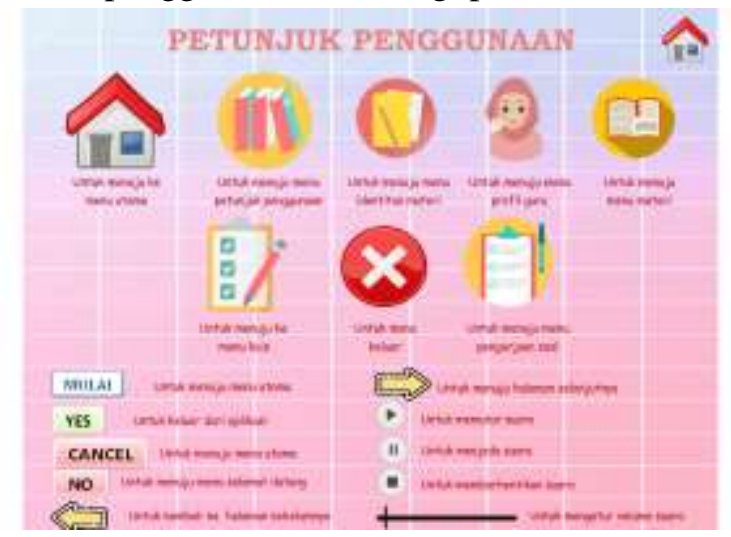

Gambar 6. Menu Petunjuk Penggunaan

f. Menu profil. Pada menu ini ditampilkan profil dari pengembang media.

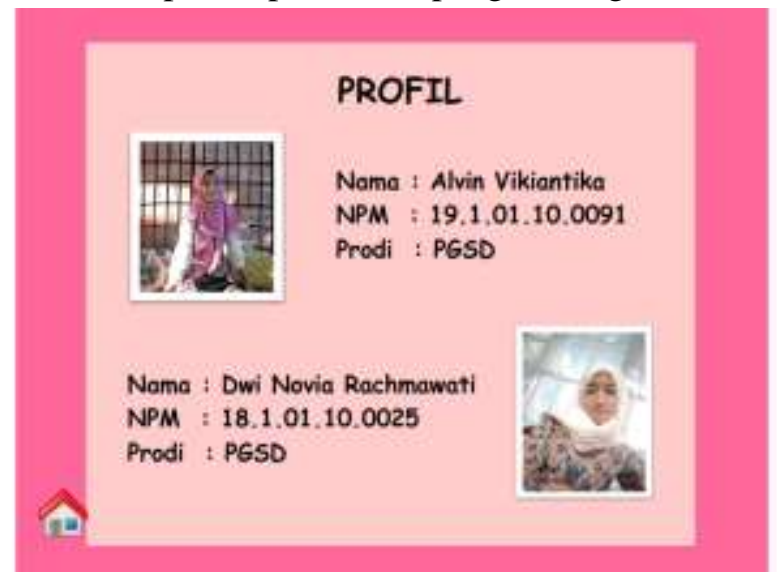

Gambar 7. Menu Profil

g. Menu kuis yang berisi 10 pertanyaan berupa pilihan ganda. Menu kuis ini dipergunakan untuk menlai kemampuan peserta didik dalam mengetahui materi siklus hidup hewan. Sebelum masuk ke dalam kuis, pengguna diminta untuk membaca petunjuk pengerjaan soal dan mengisi nama di dalam kotak yang telah disediakan. 


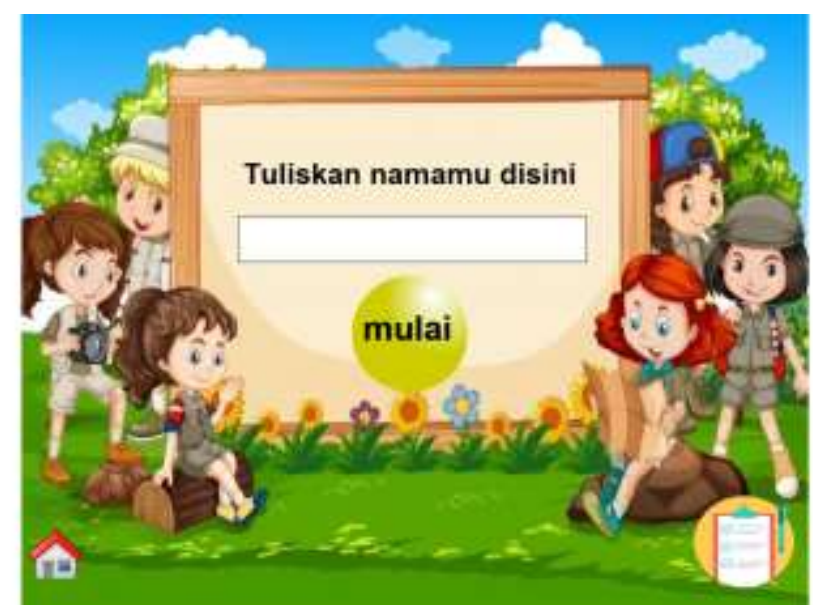

Gambar 8. Menu Kuis

\section{KESIMPULAN}

Pengembangan media SIDUWAN merupakan inovasi pengembangan media pembelajaran yang bermanfaat untuk memudahkan guru dalam menyajikan materi terkait siklus hidup hewan sekaligus dapat membangun suasana belajar aktif dan menyenangkan sehingga menaiknya hasil belajar siswa. Penelitian ini menggunakan metode research and development $(R \& D)$ serta model pengembangan ADDIE.

Berdarkan hasil data dan pembahasan penelitian, maka ditarik kesimpulan bahwa media SIDUWAN valid serta layak untuk digunakan sebagai sarana belajar peserta didik kelas IV. Sebab, hasil presentase berasal dari uji validasi ahli materi yaitu sebesar $78 \%$ dengan kategori valid. Adapun uji validasi media diperoleh data bahwa secara keseluruhan aspek mendapatkan persentase 94\% dengan kategori sangat valid.

Selain itu bahwa media SIDUWAN praktis diterapkan di sekolah sebagai sarana pendukung dalam memberikan isi materi yang diajarkan. Hal ini dicermati dari hasil evaluasi ahli praktisi pembelajaran SDN Sukorame 4 sebesar 97\%, dan penilaian ahli praktisi pembelajaran SDN Lirboyo 2 sebesar 93\% dengan kategori sangat valid. Begitu juga dengan respon siswa yang menunjukkan secara keseluruhan siswa pada skala kecil dan skala besar setuju dengan kriteria yang peneliti cantumkan pada angket respon siswa.

Keefektifan dari media SIDUWAN dilihat berdasarkan hasil dari perbandingan antara uji awal (pretest) dan uji akhir (postest) pada skala kecil memiliki nilai signifikansi 0,003. Sedangkan nilai signifikansi untuk skala besar sebanyak 0,002. Sehingga dapat disimpulkan bahwa nilai signifikansi kurang dari 0,05 , maka diperoleh hasil bahwa terdapat pengaruh yang signifikan dalam penggunaan media SIDUWAN terhadap peningkatan hasil belajar peserta didik.

Dari hasil penelitian yang telah dilaksanakan, saran untuk guru yaitu guru dapat membuat media pembalajaran interaktif guna menarik perhatian siswa saat proses pembelajaran, misalnya dengan membuat media berbasis Macromedia Flash 8.0. Sebab media tersebut dapat menyajikan berbagai tampilan animasi yang dapat disesuaikan menggunakan kebutuhan pada materi dan disertai dengan musik yang menarik.

Adapun keterbatasan dari penelitian dan pengembangan media ini yaitu (1) nilai pengerjaan soal yang terdapat di menu kuis belum bisa terekam pada akun guru, (2) media ini hanya dapat ditampilkan di laptop, (3) dalam pembuatan media memerlukan waktu yang lama, dan (4) memerlukan sarana pendukung seperti LCD Proyektor jika diimplementasikan di dalam kelas. 
DOI: https://doi.org/10.31004/basicedu.v5i6.1748

\section{UCAPAN TERIMA KASIH}

Penulis mengucapkan terima kasih pada seluruh pihak yang terlibat pada penelitian serta penulisan ini. Terima kasih penulis ucapkan pada :

Tuhan YME yang selalu memberikan kekuatan sehingga mampu menuntaskan penelitian dan penulisan ini. Bapak Kukuh Andri Aka selaku Kaprodi PGSD, Ibu Ita Kurnia selaku pembimbing utama, Bapak Aan Nurfahdianto selaku validator media, Pak Dhian Nur Wenda selaku validator materi, serta pihak-pihak lain yang penulis tidak mampu saya tuliskan satu persatu.

\section{DAFTAR PUSTAKA}

Akbar, S. (2013). Instrumen Perangkat Pembelajaran. Remaja Rosyakarya.

Arina, D., Mujiwati, E.S., Kurnia, I. (2020). Pengembangan Multimedia Interaktif Untuk Pebelajaran Volume Bangun Ruang Di Kelas V Sekolah Dasar. Jurnal Ilmiah Kependidikan, 1. Https://Doi.Org/Https://Doi.Org/10.37478/Jpm.V1i2.615

Arsyad, A. (2014). Media Pembelajaran. Pt. Raja Grafindo Persada.

Djaali. (2008). Skala Likert. Pustaka Utama.

Fadillah, M. (2014). Implementasi Kurikulum 2013 Dalam Pembelajaran Sd/Mi, Sd/Mts, Dan Sma/Ma. ArRuzz.

Faridy, D. V., Untari, E., \& Mudiono, A. (2019). Pengembangan Media Pembelajaran Cd Interaktif Siklus Hidup Hewan Di Kelas Iv Sd. Wahana Sekolah Dasar.

Gafur, A. (2012). Desain Pembelajaran (Yogyakarta). Penerbit Ombak.

Karunia, F. S. (2017). Pengembangan Media Pembelajaran Berbasis Macromedia Flash 8 Pelajaran Ipa Materi Energi Listrik Kelas Vi Di Sd. Skripsi.

Muakhirin, B. (2014). Peningkatan Hasil Belajar Ipa Melalui Pendekatan Pembelajaran Inkuiri Pada Siswa Sd. Jurnal Ilmiah Guru "Cope."

Muwaffaq, A., \& Lilik, M. (2017). Pengembangan Media Pembelajaran Macromedia Flash 8 Berbasis Pendekatan Konsep. Proceeding Biology Education Conference, 14, 441-447.

Pratiwi, M.A., \& Jasril, I. R. (2019). Pengaruh Penggunaan Macromedia Flash 8.0 Terhadap Hasil Belajar Dasar Listrik Dan Elektronika. Jurnal Vokasional Teknik Elektronika Dan Informatika, 7.

Rahmi, M. S. M., Budiman, M. A., \& Widyaningrum, A. (2019). Pengembangan Media Pembelajaran Interaktif Macromedia Flash 8 Pada Pembelajaran Tematik Tema Pengalamanku. International Journal Of Elementary Education. Https://Doi.Org/10.23887/Ijee.V3i2.18524

Riyadi, S., \& Pardjono, P. (2014). Pengembangan Multimedia Pembelajaran Matematika Berbasis Komputer Untuk Kelas Viii Smp. Jurnal Inovasi Teknologi Pendidikan. Https://Doi.Org/10.21831/Tp.V1i2.2527

Safitri, A., Putri, F.S., Fauziyyah, H., \& P. (2021). Pendidikan Di Masa Pandemi Covid-19 Dalam Penerapan Kurikulum 2013. Jurnal Basicedu, 5.

Sugiyono. (2015). Metode Penelitian Kombinasi (Mix Methods). Alfabeta.

Sugiyono. (2016). Sugiyono, Metode Penelitian. Sugiyono.

Suparyanti, Ratnawati, Arwin. (2017). Pengembangan Lembar Kerja Siswa Berbasis Model Pembelajaran Tematik Untuk Meningkatkan Kreativitassiswa Kelas Iv Sd 10 Koto Baru Pada Tema 6 Subtema 1. Inovasi Pendidikan, 2.

Syabrina, M., \& Sulistyowati, S. (2020). Pengembangan Media Pembelajaran Tematik Berbasis Macromedia Flash Untuk Meningkatkan Hasil Belajar Siswa Madrasah Ibtidaiyah. Tarbiyah Wa Ta'lim: Jurnal 
5995 Pengembangan Media Siduwan (Siklus Hidup Hewan) Berbasis Macromedia Flash di Sekolah Dasar - Alvin Vikiantika, Ita Kurnia, Dwi Novia Rachmawati

DOI: https://doi.org/10.31004/basicedu.v5i6.1748

Penelitian Pendidikan Dan Pembelajaran. Https://Doi.Org/10.21093/Twt.V7i1.2166

Yuniasti, A., \& Wulandari, R. (2015). Pengembangan Media Pembelajaran Ipa Berbasis Animasi Komputer Menggunakan Program Macromedia Flash 8. Jurnal Pena Sains.

Permendikbud (2014). Permendikbud Nomor 57 Tahun 2014 Tentang Kurikulum 2013 Sekolah Dasar/Madrasah Ibtidaiyah. Jakarta: Kemendikbud 